\title{
Islet amyloid polypeptide promotes beta-cell proliferation in neonatal rat pancreatic islets
}

\author{
E. Karlsson, S.Sandler \\ Department of Medical Cell Biology, Uppsala University, Uppsala, Sweden
}

\section{Abstract}

Aims/hypothesis. We aimed to clarify the role of islet amyloid polypeptide, which is expressed at early embryonic onset, in the proliferation and cell death of neonatal islet cells.

Methods. Fetal islets were prepared from pregnant rats on gestational day 21 . Islets were cultured in RPMI 1640 ( $11.1 \mathrm{mmol} / \mathrm{l}$ glucose $)+10 \%$ fetal calf serum (FCS) for $48 \mathrm{~h}$, followed by a $24-\mathrm{h}$ culture period in RPMI $1640(5.6 \mathrm{mmol} / \mathrm{l}$ glucose $)+1 \%$ FCS. The islets were then exposed to rat islet amyloid polypeptide (1-10 nmol/l) for $24 \mathrm{~h}$.

Results. Iselt amyloid polypeptide increased islet DNA synthesis (dpm/ $\mu \mathrm{g}$ of DNA $\cdot 6 \mathrm{~h}$ ) (control $1 \%$ FCS: $3634 \pm 662 ; 1 \mathrm{nmol} / 16347 \pm 1535 ; 10 \mathrm{nmol} / 1$ $5157 \pm 769 ; p<0.05$ islet amyloid polypeptide vs control). In accordance with this, a doubling of the autoradiographic labelling index was seen in immunocytochemically stained islet beta cells after exposure to
1 and $10 \mathrm{nmol} / \mathrm{l}$ islet amyloid polypeptide. Islet amyloid polypeptide at $1 \mathrm{nmol} / \mathrm{l}$ increased the islet insulin content $(202 \pm 25 \%$ of control; $p<0.01)$ and the 24 -h medium insulin concentration $(1 \mathrm{nmol} / 1$ islet amyloid polypeptide: $143 \pm 19 \%$ of control; $p<0.05)$ but at $10 \mathrm{nmol} / \mathrm{l}$ islet amyloid polypeptide these changes did not attain statistical difference. Islet amyloid polypeptide did not have any marked effect on the islet cell death frequency, suggesting that islet amyloid polypeptide is a more potent promoter of proliferation than of programmed cell death.

Conclusion/interpretation. Our data indicate islet amyloid polypeptide is a potential regulator of proliferation in neonatal pancreatic islet cells, an effect which can partly be attributed to the proliferation of beta cells. [Diabetologia (2001) 44: 1015-1018]

Keywords Alpha cell, amylin, beta cell, cell proliferation, insulin, islet amyloid polypeptide, pancreatic islet:
A study of the effect of some endogenous peptides that are synthesized and secreted from pancreatic islets could be important for understanding islet cell growth. Islet amyloid polypeptide (IAPP) is a $37 \mathrm{ami}$ no acid peptide that is co-secreted with insulin from

Received: 14 March 2001 and in revised form: 7 May 2001

Corresponding author: Dr. Ella Karlsson, Department of Medical Cell Biology, Biomedicum, P. O. Box 571, SE-751 23, Uppsala, Sweden, E-mail: Ella.Karlsson@medcellbiol.uu.se Abbreviations: GH, growth hormone; FACS, fluorescence activated cell sorting; FCS, fetal calf sreum; LI, labelling index; IAPP, islet amyloid polypeptide; PI, propidium iodide; RPMI, Rosewell Park Memorial Institute; TUNEL, terminal deoxynucleotidyl transferase-mediated nick end labelling beta cells. The expression of IAPP is at early embryonic-onset, i.e. the peptide coexists with insulin from the 12th gestational day in the mouse fetal pancreas [1]. IAPP has been reported to stimulate hyperplasia in some tissues, e.g. osteoblasts and proximal kidney tubule cells [2,3]. The early embryonic onset of IAPP, and the fact that it has been reported to act as a growth factor in several tissues, makes IAPP an interesting substance to study in the context of pancreatic islet growth. In this study, we aimed to investigate IAPP's role in the proliferation of neonatal alpha and beta cells. 
Table 1. Cell replication (labelling index), and cell death (TUNEL and propidium iodide positive) neonatal islet cells after IAPP exposure in vitro

\begin{tabular}{llllll}
\hline \multirow{2}{*}{ Exposure } & \multicolumn{2}{l}{ Cell replication } & & \multicolumn{2}{l}{ Cell death } \\
\cline { 2 - 3 } \cline { 5 - 6 } & $\begin{array}{l}\text { Thymidine positive cells/ } \\
\text { insulin positive cells }(\%)\end{array}$ & $\begin{array}{l}\text { Thymidine positive cells/ } \\
\text { glucagon positive cells }(\%)\end{array}$ & & $\begin{array}{l}\text { TUNEL positive cells } \\
\text { (\%) of islet cells }\end{array}$ & $\begin{array}{l}\text { Propidium iodide positive } \\
\text { cells }(\%) \text { of islet cells }\end{array}$ \\
\hline $1 \%$ FCS (Control) & $3.0 \pm 0.5$ & $7.8 \pm 0.9$ & $2.5 \pm 0.6$ & $7.6 \pm 1.4$ \\
$10 \%$ FCS & $5.4 \pm 0.6$ & $11.6 \pm 1.0^{\mathrm{a}}$ & $10.0 \pm 1.8$ & $2.5 \pm 0.4$ & $6.1 \pm 1.1$ \\
$1 \mathrm{nmol} / \mathrm{l}$ IAPP & $5.9 \pm 1.0^{\mathrm{a}}$ & $10.2 \pm 1.0$ & $2.9 \pm 0.6$ & $6.5 \pm 1.2$ \\
$10 \mathrm{nmol} / \mathrm{l}$ IAPP & $5.9 \pm 1.0^{\mathrm{a}}$ & $1.2 \pm 0.4$ & $8.5 \pm 3.2$ \\
\hline
\end{tabular}

The results of the cell replication experiments are based on two series of experiments and the control values are pooled from these two series. Values are Means \pm SEM for 14 (control, $10 \% \mathrm{FCS})$ and 8 (1 and $10 \mathrm{nmol} / \mathrm{l})$ islet preparations. ${ }^{\mathrm{a}} \mathrm{de}-$

\section{Materials and methods}

Animals, islet isolation and culture. Fetal islets were prepared on gestational day 21 from pregnant Sprague-Dawley rats [4]. The islets were cultured in Rosewell Park Memorial Institute (RPMI) $1640+10 \% \quad(\mathrm{v} / \mathrm{v})$ fetal calf serum (FCS) at $11.1 \mathrm{mmol} / \mathrm{l}$ glucose for $48 \mathrm{~h}$ thereafter designated neonatal islets. After handpicking, the islets were kept free-floating in medium RPMI 1640 containing $5.6 \mathrm{mmol} / 1$ glucose supplemented with $1 \%$ (v/v) FCS for $24 \mathrm{~h}$. The islets were then exposed to ratIAPP ( 1 and $10 \mathrm{nmol} / \mathrm{l}$ ) (Peninsula Laboratories, St. Helens Merseyside, UK) in RPMI $1640+1 \%$ FCS at $5.6 \mathrm{mmol} / \mathrm{l}$ glucose for another $24 \mathrm{~h}$. In this study, a lower concentration of FCS (1\%) was used to obtain suitable experimental conditions [5]. Control islets were exposed to $1 \%$ (v/v) FCS at $5.6 \mathrm{mmol} / \mathrm{l}$ glucose. FCS at $10 \%$ was used as positive control because it stimulates neonatal islet-cell proliferation [6].

After culture, the medium was removed and analysed for insulin by radioimmunoassay. Islets were also homogenised in water and a fraction of the homogenate was analysed for DNA content and another fraction was mixed with acid-ethanol from which insulin was extracted.

Immunohistochemistry and autoradiography. Groups of 100 islets, cultured for $24 \mathrm{~h}$, with or without 1 or $10 \mathrm{nmol} / \mathrm{l}$ IAPP in RPMI $1640+1 \%$ FCS at $5.6 \mathrm{mmol} / \mathrm{l}$ glucose, were exposed during the last $6 \mathrm{~h}$ of culture to $1 \mu \mathrm{Ci} / \mathrm{ml}\left[\right.$ methyl $\left.^{-3} \mathrm{H}\right]$ thymidine. Control islets were kept in RPMI $1640+10 \%$ FCS (5.6 mmol/l glucose). The islets were washed in Hanks' solution containing $10 \mathrm{mmol} / \mathrm{l}$ thymidine and then further washed in phosphate-buffered saline, fixed in formalin, embedded in paraffin and sectioned $(5 \mu \mathrm{m})$. The islets were stained for insulin with an antibovine insulin antibody (BioMakor, Rehovot, Israel) and for glucagon using an antiporcine antibody (NovoNordisk, Bagsvard, Denmark). The slides were rinsed in water to remove diaminobenzidine tetrahydrocloride. Wet slides were dipped in $50 \%$ film-emulsion (autoradiography emulsion, Kodak, N. Y., USA), in $0.75 \mathrm{mmol} / \mathrm{l}$ ammonium-acetate and the films exposed for 3 days before being developed, fixed and counterstained with Mayer's haematoxylin.

Microscopic evaluation. Insulin-positive and glucagon-positive cells were counted in a light microscope $(400 \times)$ and cells with 10 black silver grains or more covering the nuclei were considered to be in the S-phase of the cell cycle. There was a clear difference between background thymidine incorporation (in general $\leq 3$ grains/nucleus). The observer was not aware of the identity of the samples. The fraction of labelled cells was mea- note $p<0.01$ versus control ( $1 \%$ FCS), using Student's unpaired $t$-test. For the cell death assessments values are means \pm SEM from 8-9 different experiments

sured and expressed as labelling index (LI, number of labelled cells $\cdot 100 /$ total number of cells). To obtain accurate measurements of LI at least 500 neonatal cells were counted in each preparation.

Terminal deoxynucleotidyl transferase-mediated nick end labelling (TUNEL) and propidium iodide (PI) staining. The TUNEL labelling and the labelling index estimations were done on separate slides $(5 \mu \mathrm{m})$. The TUNEL labelling was carried out essentially according to Gavrieli et al. [7]. A sectioned ileum was used as positive control.

For propidium iodide (PI) staining islet cells were analysed by fluorescence-activated cell sorting (FACS) after exposure to 1 and $10 \mathrm{nmol} / \mathrm{l}$ IAPP in a separate series of experiments, as a measure of dead cells. Groups of 20-30 islets were incubated with IAPP for $24 \mathrm{~h}$, then exposed to PI $(10 \mu \mathrm{l} / \mathrm{ml})$ in the culture dish and trypsinized for $5 \mathrm{~min}$ at $37 \mathrm{C}$. Groups of 10000 islet cells were thereafter analysed for changes in light scattering and fluorescence emission by exciting the cells at $488 \mathrm{~nm}$ and examining fluorescence at $650 \mathrm{~nm}$. Propidium iodide is a polar dye that stains apoptotic and necrotic cells, the latter with high intensity [8]. Untreated cells were gated on a forward scatter versus PI fluorescence dot plot and the same gates were then applied to the IAPP exposed cells for calculation of the fraction of dead cells.

Statistical analysis. One observation corresponded to islets from one litter. Means \pm SEM were subsequently calculated and groups of data were compared, using Student's paired, or unpaired, $t$-test. A $p$ value of less than 0.05 was considered to be statistically significant.

\section{Results}

Cell replication in neonatal islets. In pilot experiments, we found that IAPP (1-1000 nmol/l) increased neonatal islet cell ${ }^{3} \mathrm{H}$-thymidine incorporation (data not shown). We then measured the autoradiographic LI and found a doubling in islet beta cells after exposure to 1 and $10 \mathrm{nmol} / 1 \mathrm{IAPP}$ for $24 \mathrm{~h}$ (Table 1 ). A stimulatory effect by IAPP, of the same magnitude as seen after exposure of islets to $10 \%$ FCS, was observed. Unstimulated alpha cells showed a markedly higher proliferation rate compared with the unstimulated beta cells (Table 1; alpha cells: $7.8 \pm 0.9 \%$ vs beta cells: $3.0 \pm 0.5 \%, n=8-12 ; p<0.01)$. There was 


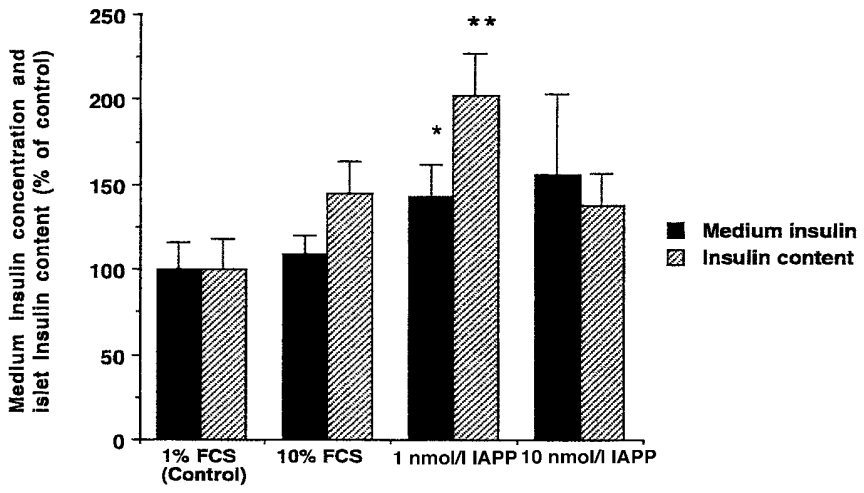

Fig.1. The effect of IAPP exposure on medium insulin accumulation ( $\square$ ) and islet insulin content (U) after neonatal islet culture for $24 \mathrm{~h}$. Data are expressed as a percentage of the $1 \%$ FCS control. The medium insulin concentration in the control was $101 \pm 16 \mathrm{pmol}$ insulin $/ 10$ islets $/ 2.5 \mathrm{ml}$. The control insulin content was $452 \pm 81 \mathrm{pmol}$ insulin $/ \mu \mathrm{g}$ DNA. Values are Means \pm SEM for 7-12 observations. * and ** denote $p<0.05$ and $p<0.01$ versus $1 \%$ FCS, respectively, using Student's paired $t$-test

a tendency towards a minor increase in the labelling index for alpha cells, however, this did not attain statistical significance. The difference in the proliferation rate between alpha and beta cells remained but decreased in the presence of IAPP as a result of the increased beta-cell proliferation. A lower concentration of IAPP $(0.1 \mathrm{nmol} / \mathrm{l})$ did not change islet cell replication when tested in a separate series by measuring ${ }^{3} \mathrm{H}$-thymidine incorporation biochemically $(\mathrm{dpm} / 10$ islets $\mathrm{x} 6 \mathrm{~h} ; n=6)$. Thus, a stimulatory effect was seen at $1 \mathrm{nmol} / 1 \mathrm{IAPP}$, but not at $0.1 \mathrm{nmol} / \mathrm{l}$ (control $1 \%$ FCS: $85 \pm 8 ; 0.1 \mathrm{nmol} / 1 \mathrm{IAPP} 109 \pm 24$ (NS vs control); $1 \mathrm{nmol} / 1 \mathrm{IAPP} 132 \pm 25 ;(p<0.05$ vs control $))$.

TUNEL positivity and PI staining. Scattered solitary TUNEL positive cells were found in the neonatal islets. IAPP at 1 or $10 \mathrm{nmol} / \mathrm{l}$ did not have any marked effect on the islet apoptosis frequency (Table 1). Neonatal islet cells were also analysed by FACS for PI staining. No effect was seen on the number of dead islet cells at 1 and $10 \mathrm{nmol} / \mathrm{l}$ IAPP.

Islet insulin content and medium insulin content. At 1 $\mathrm{nmol} / \mathrm{l}$ IAPP induced a doubling of the islet insulin content when this was analysed in relation to DNA content in order to correct for islet size (Fig. 1). The higher concentration of IAPP, as well as $10 \%$ FCS, caused an approximately $50 \%$ increase in insulin content but these differences did not attain statistical significance. The medium insulin concentration was significantly increased when islets had been cultured in the presence of $1 \mathrm{nmol} / \mathrm{l}$ IAPP (Fig. 1). The increase in insulin accumulation tended to be even higher at $10 \mathrm{nmol} / \mathrm{l}$ IAPP but this was not statistically significant. The islet DNA content did not differ between the groups (data not shown).
The increased medium insulin accumulation at $1 \mathrm{nmol} / 1$ IAPP did not seem to be a direct effect of any change in the beta-cell response to glucose, i.e. IAPP had no effect on islet insulin release at $17 \mathrm{mmol} / \mathrm{l}$ glucose (control, $1 \%$ FCS: $5.7 \pm 0.9 \mathrm{pmol} /$ 10 islets vs $1 \mathrm{nmol} / 1$ IAPP: $5.9 \pm 0.6 \mathrm{pmol} / 10$ islets; $n=6)$.

\section{Discussion}

In this study, we found that IAPP stimulated neonatal beta-cell proliferation. A doubling of the autoradiographic labelling index was seen in the beta cells after exposure to 1 and $10 \mathrm{nmol} / \mathrm{l}$ of IAPP. This was an increase of the same magnitude as that ascribed to growth hormones in previous studies [9]. The cell proliferative effect by IAPP was accompanied by an increase in islet insulin content and medium insulin accumulation. Long-term experiments with IAPP for 6 days, with new IAPP every second day (data not shown), revealed that the effect of IAPP on medium insulin was transient with IAPP having an effect within $48 \mathrm{~h}$ but not when present for 4 and 6 days. Most studies seem to favour the role of IAPP as an inhibitory substance for insulin secretion, at least when IAPP concentrations are increased under sustained conditions. It cannot be excluded that the transient increase in medium insulin might be due to an inhibitory effect of IAPP on insulin secretion when IAPP was present continuously for several days.

The net effect of IAPP on the beta-cell mass is dependent not only on the proliferation rate but also on the apoptosis frequency. We therefore used two different methods to investigate this issue. No effect by 1 or $10 \mathrm{nmol} / \mathrm{l}$ IAPP, was seen on the number of dead cells when analysed for PI positivity by FACS analysis or by TUNEL staining. The intensity of the PI staining seemed to indicate, that the PI positive group consisted mostly of apoptotic cells. A minority of the cells in each experimental group showed a more extensive uptake of PI, which might be interpreted as a sign of necrosis.

In conclusion, we show that IAPP stimulated neonatal islet-cell proliferation. A doubling of the autoradiographic LI was seen in the beta cells after exposure to 1 and $10 \mathrm{nmol} / \mathrm{l}$ IAPP. Islet alpha-cell proliferation was less affected by the IAPP exposure. In contrast to the increased beta-cell LI, no effect was seen on the apoptosis frequency. Thus, we believe that IAPP is a more effective promoter of proliferation than of programmed cell death. The early embryonic onset of IAPP expression and the effects shown in this study indicate IAPP might have a role in the growth and development of pancreatic islets during fetal life.

Acknowledgements. The skilful technical assistance of I-B. Hallgren, A. Nordin and E. Törnelius is greatly acknowledged. 
We are thankful to Dr. L. Christmansson for valuable discussions at an initial stage of the study, Dr. A. King for linguistic revision and to Dr. N. Welsh for advice regarding the FACS analysis. This study was supported by grants from the Swedish Society for Medical Research, the Swedish Medical Research Council (72X-8273), the Novo-Nordisk Foundation, the Swedish Diabetes Association, by the Juvenile Diabetes Research Foundation International, the Wallenberg Fund and the Ernfors Family Fund.

\section{References}

1. Rindi G, Terenghi G, Westermark G, Westermark P, Moscoso P, Polak JM (1991) Islet amyloid polypeptide in proliferating pancreatic B cells during development, hyperplasia, and neoplasia in human and mice. Am $\mathbf{J}$ Pathol 138: 1321-1334

2. Villa I, Rubinacci A, Ravasi F, Ferrara AF, Guidobono F (1997) Effects of amylin on human osteoblast-like cells. Peptides 18: 537-540
3. Harris PJ, Cooper ME, Hiranyachattada S et al. (1997) Amylin stimulates proximal tubular sodium transport and cell proliferation in the rat kidney. Am J Physiol 272: F13-F21

4. Hellerström C, Lewis NJ, Borg H, Johnson R, Freinkel N (1979) Method for large-scale isolation of pancreatic islets by tissue culture of fetal rat pancreas. Diabetes 28: 769-776

5. Gospodarowicz D, Moran JS (1976) Growth factors in mammalian cell culture. Annu Rev Biochem 45: 531-558

6. Hulinsky I, Hulinska H, Silink M (1995) DNA synthesis in cultured neonatal rat islets - a comparison of two methods. Diabetes Res Clin Pract 27: 119-126

7. Gavrieli Y, Sherman Y, Ben-Sasson SA (1992) Identification of programmed cell death in situ via specific labeling of nuclear DNA fragmentation. J Cell Biol 119: 493-501

8. Hortelano S, Lopez-Collazo E, Bosca L (1999) Protective effect of cyclosporin A and FK506 from nitric oxide- dependent apoptosis in activated macrophages. Br J Pharmacol 126: $1139-1146$

9. Svensson C (1996) Effects of growth hormone in vitro on the glucose metabolism of fetal rat islet B-cells. J Mol Endocrinol 17: 131-138 